\title{
HUBUNGAN PENDIDIKAN, KEBIASAAN OLAHRAGA, DAN POLA MAKAN DENGAN KUALITAS HIDUP LANSIA DI PUSKESMAS WONOKROMO SURABAYA
}

\author{
CORRELATIONS OF EDUCATIONS, EXERCISE HABITS AND DIET WITH \\ QUALITY OF LIFE IN ELDERLY AT PUSKESMAS WONOKROMO SURABAYA
}

\author{
Aviana Gita Lara, Atik Choirul Hidajah \\ ${ }^{1.2}$ Departemen Epidemiologi, \\ Fakultas Kesehatan Masyarakat, Universitas Airlangga \\ Email : avianagitalara@gmail.com
}

\begin{abstract}
Diabetes mellitus (DM) type 2 is one of the Non Comunicable Disease (NCDs) whose prevalence continue to increase. Riskesdas 2013 indicate an increasing in the prevalence of type 2 diabetes in the elderly, namely from the year 2007 increased by 3,7\% to 4,8\% in 2013. SUSENAS 2014 showed morbidity rate in the elderly in 2014 reached 25,05\%. The increasing age of elderly make elderly suffered a setback in many ways, which affects the quality of life of the elderly. Type 2 diabetes in the elderly if not keep glucose levels either by exercise will cause complications. One of the complications of type 2 diabetes mellitus is a microvascular complications. This study aimed to analyze the relationship between exercise habits and symptoms of microvascular complications with quality of life of elderly patients with type 2 DM in Puskesmas Wonokromo. This type of research is observational analytic study with sample of elderly patients with DM 2 who was treated at the Puskesmas Wonokromo as many as 96 samples. The technique sampling was Simple Random Sampling. The data analysis used Chi Square Test. The results showed no corrrelations between education and diet with quality of life, theres was a corrrelations exercise habits and quality of life $(p=0.005)$. Expected that elderly patients with type 2 diabetes were can improve the quality of life with regular exercise.
\end{abstract}

Keywords: T2 Diabetes mellitus, Quality of life, Elderly

\begin{abstract}
Abstrak :Diabetes mellitus (DM) tipe 2 merupakan salah satu Non Comunicable Diseases (NCDs) yang prevalensinya terus meningkat. Hasil Riskesdas tahun 2013 menunjukkan peningkatan angka prevalensi DM tipe 2 pada lansia meningkat dari tahun 2007 sekitar 3,7\% meningkat menjadi 4,8\% pada tahun 2013. Hasil SUSENAS tahun 2014 menunjukkan angka kesakitan (morbidity rate) pada lansia tahun 2014 mencapai 25,05\%. Pertambahan usia lansia membuat lansia mengalami kemunduran dalam berbagai hal, yang berpengaruh pada kualitas hidup lansia. Penelitian ini bertujuan untuk menganalisis hubungan pendidikan, kebiasaan olahraga dan pola makan dengan kualitas hidup lansia penderita DM tipe 2 di Puskesmas Wonokromo. Jenis penelitian ini adalah observasional analitik dengan sampel penelitian lansia penderita DM 2 yang berobat di Puskesmas Wonokromo sebanyak 96 sampel dengan pengambilan sampel secara Simple Random Sampling. Analisis data menggunakan uji Chi Square Test. Hasil penelitian menunjukkan tidak ada hubungan pendidikan dan pola makan dengan kualitas hidup, terdapat hubungan kebiasaan olahraga dengan kualitas hidup $(p=0,005)$. Diharapkan lansia penderita DM tipe 2 mampu meningkatkan kualitas hidup dengan rutin berolahraga.
\end{abstract}

Kata kunci: Diabetes Mellitus tipe 2, Kualitas hidup, Lansia

\section{PENDAHULUAN}

Non Comunicable Diseases $(N C D s)$ merupakan satu dari sekian masalah kesehatan dan tantangan dalam pembangunan di abad 21. Masalah tersebut berdampak pada beban negara yang meningkat pada negara yang sedang berkembang. Penyakit tidak menular atau Non Comunicable Disease merupakan penyakit dengan biaya penangannya yang mahal. Suatu negara tidak dapat mengabaikan adanya peningkatan penyakit seperti Diabetes Mellitus tipe 2. Bustan (2007) menyebutkan penyakit Diabetes Mellitus (DM) merupakan salah satu penyakit kronis dengan prevalensi yang meningkat.

Klasifikasi DM terbagi menjadi 3 bentuk yaitu, DM tipe 1 (Insulin-dependent- 
diabetes mellitus/IDDM), DM tipe 2 (Non-Insulin-dependent diabetes mellitus/ NIDDM), DM Gestational (Sutanto, 2010). Penyakit DM tipe 2 merupakan penyakit metabolik yang disebabkan oleh naiknya kadar glukosa darah akibat penurunan kualitas insulin pada pankreas, hormon insulin yang dihasilkan tidak berfungsi dengan baik sehingga kadar glukosa dalam darah meningkat (Tjandra, 2014). Penegakkan diagnosis DM pada seseorang yaitu dengan pemeriksaan kadar glukosa darah bukan dengan glukosuria (glukosa dalam urin). Penegakkan diagnosis DM selanjutnya dianjurkan menggunakan metode pemeriksaan glukosa secara enzimatik dengan bahan darah plasma vena (Suyono, 2011).

Menurut Tjandra (2014), kriteria dari International Diabetes Federation (IDF), American Diabetes Assciation (ADA), dan Perkeni, seseorang terdiagnosa menderita diabetes apabila kadar glukosa dalam darah saat puasa diatas $126 \mathrm{mg} /$ dL dan kadar glukosa darah setelah dua jam sesudah makan $>200 \mathrm{mg} / \mathrm{dL}$. Gejala khas dari penyakit DM tipe 2 terdiri dari banyak makan (polyphagia), banyak kencing (poliuria), dan banyak minum (polidipsia). Gejala lain dari penyakit DM tipe 2 antara lain kesemutan, luka sulit sembuh, rasa menyerupai flu, capek, lemah, dan nafsu makan menurun. Kadang dijumpai dengan mata kabur, kulit kering dan gatal pada kemaluan. Terdapat faktor risiko DM antara lain yaitu usia, keturunan, ras atau etnis, obesitas, badan kurang gerak, kehamilan, infeksi virus, stres, dan obat-obatan. Seseorang dengan DM yang terlambat mengunjungi dokter untuk mendapatkan diagnosis dokter dan pengobatan rentan terhadap timbulnya komplikasi. Pengendalian kadar glukosa darah meliputi olahraga teratur, pola makan, farmakologi dan kontrol kadar glukosa rutin. Menurut National Diabetes Statistic Report tahun 2014 menunjukkan terdapat 29,1 juta penduduk Amerika menderita DM dengan persentase usia terbanyak pada usia 65 tahun keatas sebesar 25,9\%. Riskesdas (2013) menunjukkan angka prevalensi DM tipe 2 pada usia lanjut menurut diagnosis dan gejala mengalami peningkatan dari tahun 2007. Tahun 2013, DM tipe 2 masuk kedalam 10 penyakit terbanyak pada lansia.

Menurut Peraturan Pemerintah Nomor 43 Tahun 2004 tentang Pelaksanaan Upaya Peningkatan Kesejahteraan Sosial Usia Lanjut bahwa lansia adalah seseorang yang telah mencapai usia 60 tahun keatas. Berdasarkan hasil SUSENAS (2014), jumlah lansia mencapai 20,24 juta jiwa, setara dengan $8,03 \%$ dari seluruh penduduk Indonesia tahun 2014. Pada aspek pendidikan lansia pada umumnya mempunyai tingkat pendidikan yang rendah. Terdapat $21,03 \%$ lansia tidak bisa baca dan tulis. Lebih dari $56,86 \%$ penduduk lansia tidak mempunyai ijazah pendidikan. Pada aspek kesehatan, semakin bertambah usia umumnya lansia banyak mengalami keluhan kesehatan. Keluhan kesehatan yang dialami lansia dalam sebulan terakhir menurut SUSENAS tahun 2014 sebanyak 37,11\% pada penduduk pra lansia (45-59 tahun), 48,39\% pada penduduk lansia (60-69tahun), sebanyak $57,65 \%$ pada penduduk lansia madya (70-79tahun), dan sebesar 64,04\% pada lansia tua(80-89tahun). Angka kesakitan (morbidity rate) merupakan terganggunya kegiatan sehari-hari lansia sebagai akibat dari keluhan kesehatan yang dialami. Angka kesakitan lansia tahun 2014 sebesar 25,05\%, berarti bahwa sekitar satu dari empat lansia pernah mengalami sakit dalam satu bulan terakhir. Menurut International Diabetes Federation, kasus DM tipe 2 tahun 2015 di Indonesia mencapai 10 juta kasus. Indonesia menduduki peringkat ke-7 dalam 10 besar negara terbanyak orang dewasa usia 20-79 tahun yang menderita DM tipe 2 .

Pengendalian kadar glukosa darah pada penderita DM tipe 2 meliputi olahraga teratur, pola makan, farmakologi dan kontrol kadar glukosa rutin. Penderita usia lanjut diketahui sulit mengatur pola makannya, apabila terkena stroke, penderita cenderung mengurangi aktivitas fisik. Pola makan bagi penderita DM tipe 2 yang benar adalah dengan menerapkan 3 hal yaitu : waktu makan, jenis makanan yang dikonsumsi, dan jumlah porsi dalam setiap kali makan harus sesuai. Waktu makan adalah jarak antara jam makan utama dengan jam menikmati snack. Mengatur jenis makanan, sesuai dengan 
menu seimbang yaitu 50-60\% karbohidrat, 15-20\% protein, dan $25-30 \%$ adalah lemak. Saat mengatur jumlah makan setiap hari dengan porsi yang sama karena makan juga akan memenuhi kebutuhan kalori. Pada aspek olahraga, lansia tidak dianjurkan untuk olahraga secara berlebihan. Olahraga pada lansia terutama penderita DM tipe 2 adalah olahraga tingan namun tetatur.

Menurut WHO (2004) Kualitas hidup (Quality of Life) merupakan persepsi individu dalam hidupnya yang ditinjau dari konsteks budaya, perilaku dan sistem nilai dimana mereka tinggal dan berhubungan dengan standar hidup, harapan, kesenangan, dan penilaian individu terhadap posisi mereka dalam kehidupan. Menurut WHO, pengukuran kualitas hidup mencakup kesehatan fisik, kesehatan psikologis, tingkat kebebasan, hubungan sosial, dan hubungan dengan lingkungan mereka. WHO mempunyai instrumen dalam mengukur kualitas hidup seseorang, yaitu WHOQOL-100 dan WHOQOL-BREF. Instrumen WHOQOL-BREF telah banyak diterjemahkan kedalam berbagai bahasa termasuk dalam bahasa Indonesia. Instrumen WHOQOL-BREF merupakan ringkasan dari WHOQOL-100 yang lebih praktis terdiri dari 4 domain yaitu aspek kesehatan fisik, aspek kesehatan psikologis, aspek hubungan sosial, dan aspek kondisi lingkungan. Dikemas kedalam 26 pertanyaan yang mewakili keempat domain tersebut, sehingga menjadi ringkas dibandingakan dengan WHOQOL-100. Instrumen WHOQOLBREF tersebut mampu menjelaskan variasi dari data yang dikumpulkan sebesar 52,9\%61,4\%. Menurut Wulandari (2004) dalam Bestari (2015), instrumen WHOQOLBREF memiliki tingkat sensitivitas $74 \%$, spesifitas 96\% dan akurasi 78\%. WHOQOLBREF merupakan alat pengukuran kualitas hidup yang sesuai untuk digunakan dalam mengukur kualitas hidup seseorang yang menderita penyakit kronis pada lansia, salah satunya adalah lansia dengan diabetes mellitus tipe 2 (Salim dkk, 2010).

Pertambahan usia pada seseorang terutama pada lansia akan membuat lansia mengalami kemunduran dalam berbagai hal, baik fisik dan mental yang berpengaruh pada kualitas hidup lansia. Kualitas hidup didefinisikan sebagai sebuah persepsi yang menggambarkan keadaan dirinya saat ini. Persepsi merupakan pengalaman tentang suatu objek, peristiwa, atau hubungan yang diperoleh dengan menyimpulkan informasi dan menafsirkannya. Persepsi tersebut dipengaruhi oleh faktor internal dan faktor eksternal diri seseorang dalam berprilaku (Notoatmojo, 2010). Berdasarkan Toha (2003), faktor internal meliputi perasaan, sikap dan kepribadian individu, keadaan fisik, proses belajar, keadaan fisik, gangguan kejiwaan, nilai dan kebutuhan minat, serta motivasi. Sedangkan faktor eksternal meliputi latar belakang keluarga, informasi yang diperoleh, pengetahuan dan kebutuhan sekitar, ukuran dan intensitas, hal-hal baru yang familiar atau ketidakasingan sesuatu. Kualitas hidup lansia sendiri merupakan hal yang kompleks, multidimensi, dan holistik yang meliputi kehidupan sosial, lingkungan, dan aspek yang terkait pada kesehatan lansia.

Beberapa alasan perlu dilakukan pengukuran kualitas hidup bagi penderita DM tipe 2. Menurut Mandagi (2010), menyebutkan bahwa Diabetes mellitus merupakan penyakit kronis yang mempunyai prognosis yang buruk atau tidak dapat disembuhkan, namun apabila kadar glukosa dalam darah dapat dikendalikan maka komplikasi dapat dicegah. Kedua, apabila kualitas hidup seseorang buruk maka akan menyebabkan gangguan metabolisme tubuh semakin buruk baik secara langsung atau tidak melalui sistim hormon yang menyebabkan stes dan berdampak pada timbulnya komplikasi. Ketiga, biaya pengobatan diabetes akan membebani suatu negara terutama negara yang sedang berkembang seperti Indonesia dimana negara tidak dapat mengabaikan biaya yang dibutuhkan dalam pengobatan diabetes mellitus. Berdasarkan data Dinas Kesehatan Kota Surabaya Diabetes Mellitus tipe 2 merupakan salah satu penyakit tidak menular yang terbanyak di Surabaya.

Puskesmas Wonokromo adalah salah satu puskesmas dengan kunjungan penderita DM tipe 2 usia lansia tertinggi dibandingkan dengan Puskesmas Jagir dan Ngagelrejo tahun 2015 di Surabaya. Penelitian ini bertujuan untuk menganalisis 


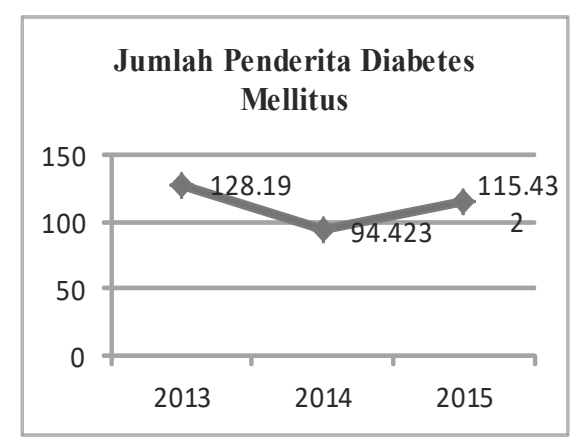

Sumber data : Laporan PTM Puskesmas Kota Surabaya Tahun 2013-2015

Gambar 1. Jumlah Penderita Diabetes Mellitus Dinas Kesehatan Kota Surabaya Tahun 20132014

hubungan antara pendidikan, kebiasaan olahraga, dan pola makan dengan kualitas hidup pada lansia penderita DM tipe 2. Tujuan khusus penelitian ini adalah mengidentifikasi karakteristik lansia penderita DM tipe 2 (usia, jenis kelamin, pendidikan, lama menderita DM tipe 2, kebiasaan olahraga, pola makan, waktu tidur, penggunaan farmakologi, gejala komplikasi mikrovaskuler, dukungan keluarga, kualitas hidup lansia penderita DM tipe 2) di Puskesmas Wonokromo Surabaya. Hasil penelitian diharapkan dapat digunakan oleh pemegang program khususnya DM tipe 2 sebagai bahan pertimbangan dan masukan mengenai masalah pada penderita DM tipe 2 khusunya lansia sehingga dapat meningkatkan kesehatan dan kesejahteraan lansia yang akan berhubungan dengan meningkatnya kualitas hidup lansia di Puskesmas Wonokromo Surabaya.

\section{METODE}

Penelitian ini merupakan penelitian observasional analitik dengan menggunakan desain cross sectional study. Lokasi penelitian dilakukan di wilayah kerja Puskesmas Wonokromo Jalan Karang Rejo VI/4 Surabaya selama kurun 6 bulan yaitu bulan Januari-Juni 2016. Populasi dalam penelitian ini adalah lansia penderita DM tipe 2 yang berobat pada periode bulan Januari-Maret 2015 di Puskesmas
Wonokromo Surabaya sebanyak 195 orang. Sampel penelitian merupakan lansia dengan usia 60 tahun keatas dan pengambilan sampel menggunakan teknik pendekatan Simple Random Sampling dengan metode pengambilan menggunakan lotre technique. Besar sampel yang digunakan pada penelitian ini sebanyak 96 orang. Variabel dependent dalam penelitian ini adalah kualitas hidup lansia, sedangkan variabel independent penelitian ini adalah pendidikan, kebiasaan olahraga, dan pola makan.

Teknik pengumpulan data menggunakan metode wawancara dan studi dokumentasi. Wawancara langsung menggunakan 2 jenis kuesioner yaitu kuesioner responden untuk mengetahui karakteristik, pendidikan, kebiasaan olahraga, dan pola makan responden serta kuesioner baku WHOQOLBREF yang telah disederhanakan bahasa untuk mengetahui kualitas hidup lansia. Wawancara dilakukan dengan mendatangi rumah responden. Sedangkan studi dokumentasi pada data Dinas Kesehatan Kota Surabaya dan Laporan Bulanan Puskesmas Wonokromo, hal ini dilakukan untuk mengetahui data sekunder dari jumlah penderita DM tipe 2 di Puskesmas Wonokromo. Data yang diperoleh akan dilakukan proses editing selanjutnya diolah dan dianalisis. Data hasil analisis deskriptif akan disajikan pada bentuk tabel distribusi dan diinterpretasikan dalam bentuk narasi. Analisis analitik menggunakan uji statistik Chi-Square.

\section{HASIL PENELITIAN}

Karakteristik responden penelitian ini meliputi usia, jenis kelamin, lama menderita DM tipe 2, waktu tidur, gejala komplikasi mikrovaskuler, penggunaan farmakologi, dukungan keluarga, dan kualitas hidup lansia. Karakteristik usia responden yang ada di Puskesmas Wonokromo Surabaya terbagi dalam lima interval kelopok usia yaitu 60 64 tahun, 65-69 tahun, 70-74 tahun, 75-79 tahun, dan $\geq 80$ tahun. Terbanyak responden pada kelompok usia 60-64 tahun dan 6569 tahun sedangkan yang terendah adalah kelompok usia $\geq 80$ tahun. Pada penelitian ini kelompok usia akan dikategorikan 
menjadi dua yaitu pada kelompok usia 60-69 tahun dan >70 tahun. Menurut jenis kelamin responden, lansia penderita DM tipe 2 berjenis kelamin perempuan lebih banyak dibandingkan dengan laki-laki, yaitu sebesar 71,9\% sebanyak 69 orang.

Berdasarkan lama menderita DM tipe 2, sebagian besar lansia menderita DM tipe 2 selama $\leq 10$ tahun yaitu sebesar 58,3\% dengan rerata menderita selama 9 tahun. Hasil penelitian menunjukkan karakteristik menurut waktu tidur lansia penderita DM tipe 2 lebih banyak memiliki waktu tidur yang buruk $(<7$ jam atau $>8$ jam $)$ sebesar $77,1 \%$ dibandingkan dengan lansia yang memiliki waktu tidur baik (7-8 jam) hanya sebesar $22,9 \%$ setiap malam.

Berikut ini merupakan tabel ringkasan distribusi karakteristik responden lansia penderita DM tipe 2 di Puskesmas Wonokromo.

Dari hasil penelitian ini diketahui bahwa lansia penderita DM tipe 2 yang mengalami gejala komplikasi lebih besar yaitu 71,9\% sedangkan yang tidak mengalami gejala komplikasi hanya sebesar 28,1 atau 27 orang. Gejala komplikasi mikrovaskuler diantaranya adalah Neuropati, Retinopati, dan Neuropati.

Dari hasil penelitian ini diketahui bahwa lansia penderita DM tipe 2 yang mengalami gejala komplikasi lebih besar yaitu 71,9\% sedangkan yang tidak mengalami gejala komplikasi hanya sebesar 28,1 atau 27 orang. Gejala komplikasi mikrovaskuler diantaranya adalah Neuropati, Retinopati, dan Neuropati. Gejala komplikasi mikrovaskuler terbanyak yaitu responden banyak mengeluhkan gejala komplikasi neurpati dengan keluhan badan sakit semua atau badan cekot-cekot. Hal ini berdampak pada waktu tidur responden, berdasarkan hasil penelitian diketahui bahwa sebagian besar lansia mengalami gejala mikrovaskuler dan sebagian besar memiliki waktu tidur yang buruk. Hasil penelitian diketahui bahwa lansia penderita DM tipe 2 sebagian besar kurang mendapat dukungan keluarga yaitu sebesar $62,5 \%$ dibandingkan dengan lansia penderita DM tipe 2 yang mendapatkan dukungan keluarga yang baik. Dalam penggunaan farmakologi, lansia penderita DM tipe 2 lebih banyak teratur
Tabel 1. Karakteristik Responden

\begin{tabular}{|c|c|c|}
\hline $\begin{array}{c}\text { Karakteristik } \\
\text { Responden }\end{array}$ & $\mathbf{n}$ & $\%$ \\
\hline \multicolumn{3}{|l|}{ Usia } \\
\hline 60-64 tahun & 28 & 29,2 \\
\hline 65-69 tahun & 28 & 29,2 \\
\hline 70-74 tahun & 26 & 27,1 \\
\hline 75-79 tahun & 9 & 9,4 \\
\hline$\geq 80$ tahun & 5 & 5,2 \\
\hline \multicolumn{3}{|l|}{ Jenis Kelamin } \\
\hline Laki-laki & 27 & 28,1 \\
\hline Perempuan & 69 & 71,8 \\
\hline \multicolumn{3}{|l|}{ Tingkat Pendidikan } \\
\hline Tidak Sekolah & 12 & 12,5 \\
\hline SD & 28 & 29,2 \\
\hline SMP & 28 & 29,2 \\
\hline SMA & 20 & 20,8 \\
\hline Perguruan Tinggi & 8 & 8,3 \\
\hline \multicolumn{3}{|l|}{ Lama Menderita DM tipe 2} \\
\hline$>10$ tahun & 40 & 41,7 \\
\hline$\leq 10$ tahun & 56 & 58,3 \\
\hline \multicolumn{3}{|l|}{ Kebiasaan Olahraga } \\
\hline Tidak Teratur & 36 & 37,5 \\
\hline Teratur & 60 & 62,5 \\
\hline \multicolumn{3}{|l|}{ Pola makan } \\
\hline Tidak Patuh & 46 & 47,9 \\
\hline Patuh & 50 & 52,1 \\
\hline \multicolumn{3}{|l|}{ Waktu Tidur } \\
\hline Buruk $(<7$ jam atau $>8$ jam $)$ & 74 & 77,1 \\
\hline Baik (7-8jam) & 22 & 22,9 \\
\hline \multicolumn{3}{|l|}{ Gejala Komplikasi } \\
\hline \multicolumn{3}{|l|}{ Mikrovaskuler } \\
\hline Mengalami & 69 & 71,9 \\
\hline Tidak Mengalami & 27 & 28,1 \\
\hline \multicolumn{3}{|l|}{ Dukungan Keluarga } \\
\hline Kurang (total skor $<3$ ) & 60 & 62,5 \\
\hline Baik (total skor $\geq 3$ ) & 36 & 37,5 \\
\hline \multicolumn{3}{|l|}{ Penggunaan Farmakologi } \\
\hline Tidak teratur & 70 & 72,9 \\
\hline Teratur & 26 & 27,1 \\
\hline \multicolumn{3}{|l|}{ Kualitas Hidup } \\
\hline Buruk (<75\% skor maksimal) & 47 & 49,0 \\
\hline Baik ( $\geq 75 \%$ skor maksimal) & 49 & 51,0 \\
\hline
\end{tabular}

Sumber: Lara (2016)

yaitu sebesar $72,9 \%$ dalam mengkonsumsi obat dibandingkan dengan yang tidak teratur yaitu sebesar $27,9 \%$. Berdasarkan hasil penelitian menunjukkan bahwa lansia penderita DM tipe 2 lebih besar memiliki kualitas hidup buruk sesebas 51,0\% sedangkan yang memiliki kualitas hidup baik sebesar $49,0 \%$. 
Pendidikan merupakan tingkatan pendidikan formal yang diterima dalam bangku sekolah. Tingkatan pendidikan dalam penelitian ini adalah Tidak Sekolah, SD, SMP, SMA, dan Perguruan Tinggi. Seseorang yang mempunyai kategori pendidikan rendah adalah seseorang yang termasuk Tidak sekolah, SD, dan SMP. Sedangkan seseorang yang masuk dalam kelopok kategori pendidikan tinggi adalah yang termasuk SMA dan Perguruan Tinggi. Menurut tingkat pendidikan, sebagian besar lansia penderita DM tipe 2 memiliki tingkat pendidikan rendah (Tidak sekolah, SD, dan SMP) yaitu sebesar 70,8\% sedangkan lansia pendetira DM tipe 2 yang memiliki tingkat pendidikan tinggi (SMA dan Perguruan Tinggi) hanya sebesar $29,2 \%$.

Berdasarkan Tabel 1 diketahui dari 96 responden, jumlah lansia dengan pendidikan SD dan SMP yang terbanyak yaitu $29,17 \%$ serta diketahui hanya sekitar $8,33 \%$ lansia yang menempuh jenjang pendidikan Perguruan Tinggi. Hasil dari uji statistik penelitian pada Tabel 2 menunjukkan bahwa tidak ada hubungan antara pendidikan dengan kualitas hidup lansia penderita DM tipe 2. Tidak terdapat hubungan variabel pendidikan pada lansia penderita DM tipe 2 dibuktikan dengan hasil nilai $p$-value sebesar $0,986(p<0,05)$. Hal ini berarti bahwa pendidikan tidak berhubungan dengan kualitas hidup lansia penderita DM tipe 2. Lansia penderita DM tipe 2 yang memiliki pendidikan rendah tidak mempunyai resiko 0,9 kali memiliki kualitas hidup yang buruk.

Kebiasaan olahraga adalah aktivitas fisik yang dilakukan oleh penderita DM tipe 2 secara berulang-ulang untuk meningkatkan kesegaran jasmani dengan keteraturan 3-5 kali dalam seminggu atau setiap hari kurang lebih selama 30 menit. Lansia penderita DM tipe 2 yang mempunyai kebiasaan olahraga teratur adalah lansia yang berolahraga 3-5 kali dalam seminggu atau setiap hari tidak kurang dan lebih selama 30 menit.

Diketahui bahwa lansia penderita DM tipe 2 lebih besar memiliki kebiasaan olahraga yang teratur sebesar $62,5 \%$ sedangkan yang tidak teratur sebesar $37,5 \%$. Diketahui jenis olahraga yang sering dilakukan oleh para lansia antara lain, senam, jalan kaki, bersepeda santai.
Tabel 2. Distribusi Jenis Aktivitas, Intensitas, dan Durasi Olahraga Responden

\begin{tabular}{lcc}
\hline $\begin{array}{c}\text { Jenis Aktivitas, Intensitas, } \\
\text { dan Durasi Olahraga }\end{array}$ & n & \% \\
\hline Jenis Aktivitas & 48 & 50,0 \\
Senam & 23 & 23,9 \\
Jalan Kaki & 24 & 25,0 \\
Senam dan Jalan Kaki & 1 & 1,0 \\
Senam dan Bersepeda & & \\
\hline Intensitas Olahraga & 6 & 6,3 \\
1-2 kali dalam Seminggu & 28 & 29,2 \\
Kadang-kadang & 50 & 52,3 \\
3-5 kali dalam Seminggu & 12 & 12,5 \\
Setiap hari & & \\
\hline Durasi Olahraga & 17 & 17,7 \\
$<30$ menit & 7 & 7,3 \\
>30 menit & 72 & 75,0 \\
\hline 30 menit & &
\end{tabular}

Berdasarkan Tabel 2 menunjukkan bahwa jenis olahraga yang terbanyak dilakukan oleh lansia penderita DM tipe 2 di Puskesmas Wonokromo Surabaya adalah adalah senam. Hal ini dikarenakan hampir semua responden dalam penelitian ini adalah anggota dari senam lansia yang dilakukan pada setiap Rukun Warga (RW) di Kelurahan Wonokromo. Kelurahan Wonokromo memiliki delapan rukun warga (RW) yang aktif dalam menggerakkan masyarakat terutama pada kelompok lansia sehingga lansia menjadi sehat dan mempunyai kondisi yang baik.

Berikut adalah distribusi jenis aktivitas, intensitas, durasi olahraga responden di Puskesmas Wonokromo Surabaya : Menunjukkan bahwa intensitas olahraga responden terbanyak adalah 3-5 kali dalam seminggu.

Tabel 4 menunjukkan hasil uji statistik bahwa kebiasaan olahraga berhubungan dengan kualitas hidup lansia penderita DM tipe 2. Hubungan variabel kebiasaan olahraga pada lansia DM tipe 2 dibuktikan berdasarkan dengan nilai p-value sebesar $0,005(\mathrm{p}<0,05)$. Hal ini berarti bahwa kebiasaan olahraga berhubungan dengan kualitas hidup lansia penderita DM tipe 2. Lansia penderita DM tipe 2 yang tidak teratur dalam olahraga mempunyai resiko 0,2 kali memiliki kualitas hidup yang buruk. 
Pola makan pada lansia penderita DM tipe 2 adalah pola makan dengan menerapkan pembatasan 3J (Jumlah, Jenis, dan Jadwal). Pola makan jumlah nasi dalam setiap satu kali makan tidak boleh $>10$ sendok makan. Terdapat jenis makanan yang harus dibatasi seperti roti manis, sayur bersantan. Serta makanan yang harus dipantang antara lain mangga, duku dan makanan yang menggandung gula. Serta jadwal makan yaitu rentang waktu saat makan utama dengan waktu ngemil.

Diantara 96 responden menurut pola makan, menunjukkan hasil bahwa lansia penderita DM tipe 2 yang patuh dalam pola makan lebih banyak yaitu $52,1 \%$ atau sebanyak 50 orang sedangkan yang tidak patuh pola makan sebesar $47,9 \%$ atau sebanyak 46 orang. Responden yang dinyatakan patuh adalah lansia yang menerapkan pola makan 3J (Jumlah, Jenis, dan Jadwal). Lansia yang tidak patuh dalam pola makan adalah lansia mengkonsumsi yang melebihi pola yang dianjurkan dan tidak peduli dengan jenis makanan yang dipantang serta tidak memperhatikan waktu makan.

Hasil uji statistik pada Tabel 5 menunjukkan bahwa tidak terdapat hubungan antara pola makan dengan kualitas hidup lansia penderita DM tipe 2. Hubungan variabel pola makan dibuktikan berdasarkan uji statistik dengan nilai $p$-value sebesar $0,303(p>0,05)$. Hal ini berarti bahwa pola makan tidak berhubungan dengan kualitas hidup lansia penderita DM tipe 2. Lansia penderita DM tipe 2 yang tidak patuh dalam pola makan tidak mempunyai resiko memiliki kualitas hidup yang buruk sehingga menghambat lansia dalam melakukan aktivitas sehari-hari dengan baik. Hal tersebut, baik lansia yang tidak patuh

Tabel 3. Hubungan antara Pendidikan Dengan Kualitas Hidup Lansia Penderita DM tipe 2 di Puskesmas Wonokromo Surabaya

\begin{tabular}{lcccccccc}
\hline & \multicolumn{4}{c}{ Kualitas Hidup } & \multicolumn{2}{c}{ Total } \\
\cline { 2 - 7 } & \multirow{2}{*}{ Pendidikan } & \multicolumn{2}{c}{ Buruk } & \multicolumn{2}{c}{ Baik } & \multicolumn{2}{c}{} \\
\cline { 2 - 7 } & Jumlah & $\mathbf{\%}$ & Jumlah & $\mathbf{\%}$ & Jumlah & \% \\
\hline Rendah & 33 & 48,5 & 35 & 51,5 & 69 & 100 \\
Tinggi & 14 & 50,0 & 14 & 50,0 & 28 & 100 \\
\hline & $p=0,896$ & OR $=0,9$ & CI $=0,391-0,274$ \\
\hline
\end{tabular}

Tabel 4. Hubungan antara Kebiasaan Olahraga Dengan Kualitas Hidup Lansia Penderita DM tipe 2 di Puskesmas Wonokromo Surabaya

\begin{tabular}{lccccccc}
\hline & \multirow{3}{*}{ Olahraga } & \multicolumn{4}{c}{ Kualitas Hidup } & \multicolumn{2}{c}{ Total } \\
\cline { 2 - 7 } & & \multicolumn{2}{c}{ Buruk } & \multicolumn{2}{c}{ Baik } & & \\
\cline { 2 - 7 } & & Jumlah & \% & Jumlah & \% & Jumlah & \% \\
\hline Tidak Teratur & 11 & 30,6 & 25 & 69,4 & 36 & 100 \\
Teratur & 36 & 60,0 & 24 & 40,0 & 60 & 100 \\
\hline & $p=0,005$ & OR $=0,2$ & CI $=0,122-0,705$ \\
\hline
\end{tabular}

Tabel 5. Hubungan antara Pola Makan Dengan Kualitas Hidup Lansia Penderita DM tipe 2 di Puskesmas Wonokromo Surabaya

\begin{tabular}{lccccccc}
\hline \multirow{2}{*}{ Pola Makan } & \multicolumn{3}{c}{ Kualitas Hidup } & \multicolumn{2}{c}{ Total } \\
\cline { 2 - 6 } & \multicolumn{2}{c}{ Buruk } & \multicolumn{2}{c}{ Baik } & \\
\cline { 2 - 7 } & Jumlah & $\mathbf{\%}$ & $\mathbf{n}$ & $\mathbf{\%}$ & $\mathbf{n}$ & $\mathbf{\%}$ \\
\hline Tidak Patuh & 20 & 43,5 & 40 & 58,0 & 69 & 100 \\
Patuh & 27 & 54,0 & 9 & 33,7 & 27 & 100 \\
\hline & $p=0,303$ & OR $=0,6$ & $\mathrm{CI}=0,293-1,467$ & \\
\hline
\end{tabular}


pola makan yang tidak melakukan pola makan pembatasan 3J (Jumlah, Jenis, dan Jadwal) dalam kehidupan sehari-hari.

\section{PEMBAHASAN}

Karakteristik responden berdasarkan hasil penelitian menurut usia sebagian besar lansia penderita DM tipe 2 sebagian besar pada kelompok usia 60-69 tahun. Hal ini sejalan dengan Kurniawan (2010), yang menyebutkan bahwa 50\% lansia berusia 65 tahun dan sesuai dengan data jumlah penderita DM tipe 2 di Puskesmas Wonokromo tahun 2015 dimana jumlah lansia terbanyak adalah pada usia 60-69 tahun. Menurut jenis kelamin, responden lebih banyak pada jenis kelamin perempuan. Hal ini sesuai dengan Prazeres dan Figueiredo (2014), yang menunjukkan perempuan lebih banyak daripada lakilaki. Hasil penelitian ini tidak sesuai dengan data jumlah penderita DM tipe 2 di Puskesmas Wonokromo tahun 2015 yang menyebutkan lansia perempuan dengan kelompok usia yang sama yaitu (6069tahun) dan (>70 tahun) lebih banyak pada laki-laki dibandingkan dengan perempuan. Berdasarkan Tjokroprawiro (2004), pada penderita pnyakit kronis angka insidens antara laki-laki meskipun demikian, berdasarkan Tjokroprawiro (2004), pada penderita penyakit kronis seperti diabetes mellitus tipe 2 angka insidens antara lakilaki dan perempuan masa lansia kurang lebih sama

Karakteristik menurut lama menderita DM tipe 2 terbanyak adalah pada kelompok $\leq 10$ tahun dengan rerata menderita selama 9 tahun dan terbanyak menderita selama 6 tahun. Hal ini sejalan dengan penelitian Yusra (2010), yang menyebutkan bahwa lama menderita DM tipe 2 terbanyak adalah pada rentang 5-7 tahun, disebabkan oleh penelitian menggunakan responden dengan karakteristik usia yang sama. Seseorang yang menderita DM tipe $2 \geq 11$ tahun memiliki efikasi diri yang baik daripada seseorang yang $<10$ tahun. Hal ini disebabkan oleh penderita telah perpengalaman dan mandiri dalam pengelola kondisi penyakitnya.

Berdasarkan hasil penelitian di atas, karakteristik responden menurut waktu tidur menunjukkan lansia penderita DM tipe 2 lebih banyak memiliki waktu tidur yang buruk dibandingkan dengan memiliki waktu tidur yang baik. Penelitian ini rerata waktu tidur responden selama $5 \mathrm{jam}$, hal ini sesuai dengan penelitian Luyter dan DunbarJacob (2011), yang menyebutkan lebih dari setengah jumlah pasien DM tipe 2 memiliki waktu tidur yang buruk yang disebabkan oleh nyeri akibat neuropati.

Hasil penelitian menunjukkan bahwa responden yang mengalami gejala komplikasi mikrovaskuler lebih besar dibandingkan responden yang tidak mengalami gejala komplikasi mikrovaskuler dengan terbanyak mengeluhkan adanya keluhan gejala mikrovaskuler neuropati. Hal ini berbeda dengan hasil penelitian Prazeres dan Figueiredo (2014), bahwa penderita DM tipe 2 lebih banyak tidak mengalami gejala komplikasi namun komplikasi mikrovaskuler lebih besar dibandingkan dengan komplikasi mikrovaskuler. Penelitian ini menunjukkan bahwa responden lebih besar mengalami gejala komplikasi terbanyak adalah neuropati dengan menunjukkan gejala yaitu badan cekot-cekot.

Menurut hasil penelitian, responden yang memiliki dukungan keluarga kurang lebih besar dibandingkan yang memiliki dukungan keluarga yang baik. Penelitian ini berbeda dengan Mandagi (2010) dan Yusra (2010), yang menyebutkan rerata responden lebih besar yang mendapat dukungan keluarga baik. Diketahui bahwa responden dalam penelitian ini, rerata telah menderita DM tipe 2 selama 6 tahun sehingga responden cukup mengerti dan mandiri dalam menjaga kondisinya. Fisher (2005) dalam Yusra (2010) menyebutkan bahwa responden yang baru menderita DM tipe 2 hanya selama 4 bulan telah menunjukkan efikasi diri yang baik terhadap dirinya. Dukungan keluarga menurut Sarafino (2004) dan Hensarling (2009) dalam Yusra (2010), menyebutkan bahwa dukungan keluarga memiliki 4 dimensi yaitu dimensi emosional, dimensi penghargaan, dimensi instrumental, dan dimensi informasi. Keluarga berperan dalam mendorong penderita DM tipe 2 untuk menjaga kondisinya dengan memberikan dukungan baik berupa informasi, langsung menemani penderita dalam beraktivitas, 
dan mendudung dengan memberikan biaya pengobatan DM tipe 2.

Responden yang menggunakan farmakologi secara teratur lebih banyak dibandingkan dengan yang tidak teratur. Hal ini sejalan dengan penelitian Annisa (2008), yang menunjukkan penggunaan farmakologi yang teratur lebih besar dibandingkan yang tidak teratur. Empat pilar pengendalian DM tipe 2 salah satunya adalah penggunaan farmakologi, hal ini dilakukan apabila pengelolaan diabetes mellitus non farmakologi (pola makan dan olahraga) belum tercapai, (Waspadji, 2011). Hasil penelitian menunjukkan bahwa responden yang memiliki kualitas hidup buruk lebih besar dibandingkan dengan yang memiliki kualitas hidup baik. Hal ini berbeda dengan Mandagi (2010) dimana responden lebih banyak memiliki kualitas hidup yang baik. Hal ini disebabkan oleh penggunaan instrumen untuk menghitung. Pada penelitian Mandagi (2010) menggunakan SF-36 sedangkan pada penelitian menggunakan WHOQOLBREF. Keduanya merupakan instrumen dari WHO.

Karakteristik responden menururt tingkat pendidikan labih besar responden memiliki pendidikan rendah. Sejalan dengan penelitian Martinez, et al (2008), bahwa lansia dengan DM tipe 2 menempuh pendidikan terbanyak hanya tingkat dasar. Berdasarkan SUSENAS (2014), lansia di Indonesia pada umumnya hanya memiliki pendidikan rendah dan rata-rata lansia putus sekolah dikelas 5 SD. Hasil penelitian menunjukkan bahwa tidak terdapat hubungan antara pendidikan dengan kualitas hidup lansia penderita DM tipe 2. Sejalan dengan penelitian yang dilakukan oleh Mandagi (2010), yang dilakukan di Surabaya yang menujukkan tidak ada hubungan pendidikan dengan kualitas hidup lansia penderita DM tipe 2. Berbeda dengan penelitian Martinez, et al, (2008), yang dilakukan di Mexico, hasil menunjukkan bahwa pendidikan merupakan faktor prediktor dari kualitas hidup seseorang, semakin tinggi jenjang pendidikan seseorang maka semakin taat seseorang dengan DM tipe 2 dalam melakukan pengobatan diabetes.

Pendidikan seseorang menentukan kemudahan seseorang dalam mengelola setiap pembaharuan informasi serta pengaplikasikan sebuah informasi yang baru. Pendidikan seseorang merupakan faktor yang berpengaruh pada seseorang penderita DM tipe 2 untuk dapat mengatur dan memahami dirinya dalam mengobati diabetes mellitus yang dialami.

Hasil penelitian menunjukkan bahwa responden yang berolahraga secara teratur lebih besar dibandingkan dengan responden yang tidak teratur dalam berolahraga. Diketahui bahwa responden terbanyak melakukan olahraga senam. Sebagian besar responden dalam penelitian ini merupakan anggota dari program senam lansia yang rutin dilakukan di setiap RW di Kelurahan Wonokromo sehingga jadwal untuk berolahrga sudah teratur. Hasil penelitian pada Tabel 3 menunjukkan bahwa terdapat hubungan antara kebiasaan olahraga dengan kualitas hidup lansia penderita DM tipe 2. Hal ini berarti bahwa faktor kebiasaan olahraga merupakan faktor risiko dari baik buruknya kualitas hidup lansia penderita DM tipe 2. Penelitian ini sejalan dengan penelitian Mandagi (2010), yaitu penderita DM tipe 2 harus tetap sehat, sehingga aktivitas sehari-hari akan lancar. Olahraga pada lansia penderita DM tipe 2 bermanfaat untuk menjaga kadar glukosa tetap normal, mencegah kegemukan dan mengatasi melekatnya lipid pada dinding pembuluh darah. Olahraga pada lansia harus sesuai anjuran agar tidak menimbulkan risiko akibat berlebihan olahraga (Kurniawan, 2010).

Olahraga pada lansia penderita DM tipe 2 adalah olahraga yang bersifat isotonis yang kontraksi ototnya konstans atau bersifat aerobik dimana aktivitas olahraganya ringan dan berulang seperti jalan kaki atau jogging. Olahraga pada lansia tdak perlu dilakukan berjam-jam dan berat yang menyebabkan Hipoglikemia (Kurniawan, 2010). Karakteristik responden menurut pola makan, menunjukkan bahwa lansia dengan pola makan yang patuh lebih banyak dibandingkan dengan yang tidak patuh dalam menjaga pola makan. Hasil tersebut berbeda dengan Mandagi (2010), yang menyebutkan sebagian besar responden tidak patuh pola makan. Penelitian ini sejalan dengan penelitian 
Papazafiropoulou, et al. (2015), yang menyebutkan responden lebih banyak tidak menjaga pola makan dikarenakan penderita menjadi terbatas dalam mengkonsumsi jenis makanan tertentu. Hasil dari penelitian ini diketahui bahwa responden telah mengerti jenis makanan yang dipantang untuk dikonsumsi. Tabel. 5 menunjukkan bahwa tidak terdapat hubungan antara pola makan dengan kualitas hidup lansia. Hal ini berbeda dengan penelitian yang dilakukan oleh Papazafiropoulou, et al. (2015), yang dilakukan di Yunani menunjukkan bahwa terdapat hubungan antara pola makan dengan kualitas hidup lansia. Hal tersebut disebabkan karena DM tipe 2 membuat lansia penderita tidak bebas dalam menikmati makanan sehingga kualitas hidup akan menjadi terganggu. Pola makan bagi penderita DM tipe 2 harus memperhatikan makanan Makanan serta waktu makan antara makan utama dengan snack. Pola makan bagi penderita DM tipe 2, bertujuan untuk menjaga kadar glukosa dalam darah agar tetap normal disertai dengan olahraga yang teratur. Diketahui bahwa dalam penelitian ini tidak terdapat hubungan antara pola makan dengan kualitas hidup lansia, dimana sebagian besar responden dalam penelitian ini lebih besar yang memiliki pola makan yang patuh dibandingkan yang tidak patuh serta diketahui bahwa sebagian responden telah mengetahui jenis makanan yang harus dibatasi dan jenis makanan yang harus dipantang.

\section{SIMPULAN}

Simpulan dari penelitian ini adalah faktor pendidikan tidak berhubungan dengan kualitas hidup lansia penderita DM tipe 2, sedangkan faktor kebiasaan olahraga berhubungan dengan kualitas hidup lansia penderita DM tipe 2, dan faktor pola makan tidak berhubungan dengan kualitas hidup lansia penderita DM tipe 2 di Puskesmas Wonokromo Surabaya.

\section{SARAN}

Instansi terkait perlu meningkatkan program untuk lansia penderita DM tipe 2 untuk lebih meningkatan kesejahteraan dan kualitas hidup lansia dengan aktif memberikan kegiatan promotif dan preventif baik dalam penyuluhan ataupun mengikuti kegiatan Posyandu Lansia. Masyarakat, khususnya masyarakat lansia penderita DM tipe 2 lebih aktif mengikuti senam lansia secara teratur dan melakukan olahraga ringan untuk menjaga kadar glukosa dan berat badan serta menerapkan pola pola makan kalori secara teratur dengan selalu memperhatikan jenis makanan yang dikonsumsi. Mendatangi layanan kesehatan kesehatan untuk mendapatkan informasi mengenai kondisi kesehatannya terutama pada kadar glukosa dalam darah.

\section{DAFTAR PUSTAKA}

Annisa, N.S, 2008. Faktor yang Berhubungan dengan Kualitas Hidup Penderita Diabetes Mellitus. Skripsi. Universitas Airlangga

Bestari, A.W. 2015. Faktoryang Berhubungan dengan Kualitas Hidup Pasien Penyakit Ginjal Kronis (PGK) Hemodialisi Berdasarkan WHOQOL-BREF. Skripsi. Universitas Airlangga

BPS, 2014. Statistik Usia Lanjut (Hasil SUSENAS 2014). Jakarta. BPS

Bustan, M.N. 2007. Epidemiologi Penyakit Tidak Menular. Jakarta: Rineke Cipta

Departemen Kesehatan Kota Surabaya. 2015. Laporan PTM Puskesmas Kota Surabaya Tahun 2013-2015. Depkes Kota Surabaya

Departemen Kesehatan RI. 2013. Riset Kesehatan Dasar (Riskesdas) 2013. Badan Litbangkes. Jakarta: Depkes RI

Kurniawan, I. 2010. Diabetes Mellitus Tipe 2 pada Usia Lanjut. Majalah Kedokteran Indonesia. Volum 60(12)

Lara, A.G. 2016. Faktor yang Berhubungan dengan Kualitas Hidup Lansia Penderita DM tipe 2(Studi di Puskesmas Wonokromo Surabaya). Skripsi. Surabaya: Universitas Ailangga

Luyster, F.S., Dunbar, J.J. 2011. Sleep quality and quality of life in adults with type 2 diabetes. (e-journal) Diabetes Educ. 2011 : 37(3): 347-355

Mandagi, A.M., 2010. Faktor yang Berhubungan dengan Status Kualitas Hidup Penderita Diabetes Mellitus (Studi Puskesmas Pakis Kecamatan sawahan 
Kota Surabaya). Skripsi. Surabaya: Universitas Airlangga

Martinez, Y.V., Prado-Aguilar, Carlos., Rascon-Pacheco, Ramon., ValdiviaMartinez, Jose J. 2008. Quality of life associated with treatment adherence in patients with type 2 diabetes: a cross sectional study. (articel research) $B M C$ Health Service Research 8:164.

Notoatmodjo, S. 2010. Ilmu Perilaku Kesehatan. Jakarta: Rineka Cipta.

Papazafiropoulou, K., Bakomitrou, Florentia., Trikallinou, Aikaterini., Ganotopoulou, Asimina., Verras, Chris., Christofilidis, George., Bousboulas, Stavros., and Melidonis, Andreas. 2015. Diabetesdependent quality of life (ADDQOL) an affecting factor in patients with diabetes mellitus type 2 in Greece. (research article). BMC Research Note 8:786.

Pemerintah RI. 2004. Peraturan Pemerintah Nomor 43 Tahun 2004 tentang Pelaksanaan Upaya Peningkatan Kesejahteraan Sosial Usia Lanjut. Jakarta.

Prazeres, F., Figuiredo. 2014. Measuring quality of life of old type 2 diabetic patients in primary care in Portugal:a cross-sectional study. (research article). Journal of Diabetes \& Metabolic Disorders 13:68

Puskesmas Wonokromo. 2015. Profil Puskesmas Wonokromo Tahun 2015. Surabaya: Puskesmas Wonokromo.

Salim, O., Sudharma, N., Kusumaratna, R., dan Hidayat, A. 2007. Validitas dan reliabilitas World Health Organization.
Universa Medicina, 26(1): pp.27-38. Tersedia di: http://www.univmed.org/ ejurnal/index.php/medicina/article/ download/293/246 [diakses tanggal 30 Juni 2016]

Sutanto. 2010. Cekal (Cegah dan Tangka) Penyakit Modern. Yogyakarta: Penerbit Andi.

Suyono, S. 2011. Patofisiologi Diabetes Melitus. Dalam Penatalaksanaan Diabetes Melitus Terpadu. Edisi Kedua. Jakarta : Balai Pernebit FKUI.

Tjandra, H. 2014. Stategi Mengalahkan Komplikasi Diabetes dari Kepala Sampai Kaki. 1st ed. Jakarta: PT. Gramedia Pustaka Utama.

Tjokroprawiro, A. 2007. Hidup Sehat dan Bahagia Bersama Diabetes. 10th ed. Jakarta: PT. Gramedia Pustaka Utama.

Toha, M. 2003. Kepemimpinan Dalam Manajemen. Jakarta: PT. Raja Grafindo Persada.

Waspadji, S. 2011. Diabetes Melitus: Mekanisme Dasar dan Pengelolaannya yang Rasional Dalam Penatalaksanaan Diabetes Melitus Terpadu. Edisi Kedua. Jakarta: Balai Penerbit FKUI.

WHO. 2004. Programme on Mental Health WHOQOL Measuring Quality of Life. Division of mental Health and Prevention of Subtance Abuse.

Yusra, A. 2010. Hubungan antara Dukungan Keluarga dengan Kualitas Hidup Pasien Diabetes Mellitus tipe 2 di Poliklinik Penyakit Dalam Rumah Sakit Umum Pusat Fatmawati Jakarta. Tesis. Depok. 